\title{
Impact of chemical and meteorological boundary and initial conditions on air quality modeling: WRF-Chem sensitivity evaluation for a European domain
}

\author{
Mathias Ritter • Mathias D. Müller • \\ Oriol Jorba $\cdot$ Eberhard Parlow $\cdot$ L.-J. Sally Liu
}

Received: 5 March 2012/ Accepted: 9 October 2012/Published online: 25 October 2012

(C) Springer-Verlag Wien 2012

\begin{abstract}
This study evaluates the impact of different chemical and meteorological boundary and initial conditions on the state-of-the-art Weather Research and Forecasting (WRF) model with its chemistry extension (WRF-Chem). The evaluation is done for July 2005 with $50 \mathrm{~km}$ horizontal resolution. The effect of monthly mean chemical boundary conditions derived from the chemical transport model LMDZ-INCA on WRF-Chem is evaluated against the effect of the preset idealized profiles. Likewise, the impact of different meteorological initial and boundary conditions (GFS and Reanalysis II) on the model is
\end{abstract}

Responsible editor: X.-Y. Huang.

L.-J. Sally Liu: Deceased.

M. Ritter $(\bowtie) \cdot$ M. D. Müller · E. Parlow

Meteorology, Climatology and Remote Sensing,

University of Basel, Basel, Switzerland

e-mail: mathias.ritter@unibas.ch

M. Ritter · L.-J. S. Liu

Environmental Exposure Sciences, Department of Epidemiology and Public Health, Swiss Tropical and Public Health Institute,

Basel, Switzerland

Present Address:

M. Ritter

Klingelbergstr. 27, 4056 Basel, Switzerland

O. Jorba

Earth Sciences Department, Barcelona Supercomputing Center,

Barcelona, Spain

L.-J. S. Liu

University of Basel, Basel, Switzerland

L.-J. S. Liu

Department of Environmental and Occupational Health

Sciences, University of Washington, Seattle, WA, USA evaluated. Pearson correlation coefficient between these different runs range from 0.96 to 1.00. Exceptions exists for chemical boundary conditions on ozone and for meteorological boundary conditions on $\mathrm{PM}_{10}$, where coefficients of 0.90 were obtained. Best results were achieved with boundary and initial conditions from LMDZ-INCA and GFS. Overall, the European simulations show encouraging results for observed air pollutant, with ozone being the most and $\mathrm{PM}_{10}$ being the least satisfying.

\section{Introduction}

The significance of air pollution modeling is increasing in the field of health assessment. More and more public health cohort studies are using output of air quality models (Liu et al. 2007; Cohen et al. 2009; Bellander et al. 2001), as measurements are expensive and represent only a limited area (especially in mountainous areas). There exists a variety of models to achieve valid results. One of them is the physical and chemical modeling of meteorology and air pollutants. Most of these models are offline meaning that the meteorology is calculated prior to the chemistry in two separate models. A widely used offline model for Europe is the CHIMERE model (Schmidt et al. 2001; Bessagnet et al. 2004; van Loon et al. 2004, 2007; Vautard et al. 2005; Baldasano et al. 2008; Szopa et al. 2009; Pay et al. 2010). Other often used models are the CMAQ (van Loon et al. 2004; Baldasano et al. 2008; Matthias 2008) (especially over America) and the Unified EMEP model (van Loon et al. 2004, 2007). Nevertheless, in this study an online coupled model is used where every grid point and timestep is consistent with the meteorological model. The state-of-the-art Weather Research and Forecasting (WRF) model (Skamarock et al. 2008) with a chemistry extension 
(WRF-Chem) (Grell et al. 2005) is used to simulate air pollutants. The approach of adding a chemistry module to an already existing meteorological model is applied to a variety of different meteorological models. Examples beside WRF-Chem are Enviro-HIRLAM (Korsholm et al. 2008), GEM-AQ (Kaminski et al. 2008), COSMO-ART (Vogel et al. 2009), Meso-NH-C (Tulet et al. 2003) and MCCM (Grell et al. 2000).

The overall aim of this study is to calculate concentrations of air pollutants in Switzerland for the years 1991 and 2002 where health surveys of the biggest Swiss cohort study on air pollution and lung diseases in adults (SAPALDIA) were carried out (Ackermann-Liebrich et al. 1997, 2005; Liu et al. 2007). SAPALDIA focuses on health effects from long-term exposure to air pollution within a Swiss cohort of over 8,000 participants mainly living near eight study areas (Geneva, Basel, Lugano, Aarau, Wald, Payerne, Davos, Montana), where continuous air pollution measurements were done. Some of the participants moved house between the two health survey years (1991 and 2002) and are therefore dispersed over Switzerland. For these participants the output of a high resolution air quality model is needed to obtain their air pollution exposure. The high resolution domain of Switzerland is nested into a coarser European one. This study presents a sensitivity evaluation for July 2005 on the effects of different chemical and meteorological boundary and initial conditions on the model output of the coarser European domain. Therefore, this study presents a preparatory stage for the final overall aim. July 2005 was simulated because of the absence of GFS data for the years 1991 and 2002.

\section{Method and data}

\subsection{Model description and setup}

The Weather Research and Forecasting (WRF version 3.2.1) model with the research core (ARW) was used for this study (Skamarock and Klemp 2008). The European domain covers an area from northern Africa to southern Finland with a horizontal resolution of $50 \mathrm{~km}$. This leads to a domain with $60 \times 60$ grid points for 27 vertical sigma layers. The microphysics were calculated with the Eta Ferrier scheme (Rogers et al. 2001). Other used physics options were the Bets-Miller-Janjic cumulus scheme (Janjic 1994, 2000), the Eta surface layer scheme (Janjic 1996, 2001), the Noah land-surface model (Chen and Dudhia 2001) with the USGS landuse dataset, the Mellor-YamadaJanjic planetary boundary layer scheme (Janjic 1990, 1996, 2001), the RRTM (Mlawer et al. 1997) and Dudhia scheme (1989) for the longwave and shortwave radiation, respectively. Further informations on these options can be found in Skamarock et al. (2008).

The air pollutants were simulated with the chemistry extension (WRF-Chem version 3.2.1) (Grell et al. 2005). This model is widely used in America and was already used in Europe by Schürmann et al. (2009), SanJosé et al. (2008) and Tuccella et al. (2012). Recently, the model is more and more used by European research groups which can be seen in contributions to international conferences (e.g. EGU2011). WRF-Chem is an online coupled model with several choices of chemical mechanisms and aerosol modules. A small pre-study was carried out to choose the various options (e.g. chemical mechanism, physic parameters, dynamic parameters and other chemical options) of the WRF-Chem framework. For this study the best results were achieved with the Carbon bond mechanism version $\mathrm{Z}$ (CBMZ) and the corresponding Model for Simulating Aerosol Interactions and Chemistry (MOSAIC) using four sectional aerosol bins (Zaveri and Peters 1999; Zaveri et al. 2008; Fast et al. 2006). Slightly better results were achieved with eight sectional bins but considering the additional computation time and the only little gain we decided to use only four bins. The same time steps were applied for the meteorological and the chemical calculations. The lumped CBMZ scheme consists of over 65 prognostic species and over 160 chemical reactions. The MOSAIC scheme implements primary aerosols (sea salt, soil dust, black carbon and organic carbon) as well as secondary aerosols formed by various salts, inorganic gasphase chemistry, coagulation and homogeneous nucleation. The Fast-J photolysis (Wild et al. 2000) option was applied along with a dry deposition option. The setup of this domain did not implement direct and indirect radiative feedback, wet scavenging or the formation of secondary organic aerosols, because these sub-modules were not compatible with the chosen physics options and aerosol module, respectively.

\subsection{Emissions}

Gap-filled emissions from the European Monitoring and Evaluation Programme (EMEP) were used (Vestreng and Klein 2002; EMEP 2010) as anthropogenic input for July 2005. They are available with a horizontal resolution of $50 \mathrm{~km}$ and yearly average values of several main air pollutants, heavy metals, persistent organic pollutants and particulate matter for 11 SNAP sectors (Selected Nomenclature for reporting of Air Pollutants). For this study only the main pollutants $\left(\mathrm{CO}, \mathrm{NH}_{3}, \mathrm{NMVOC}, \mathrm{NO}_{x}, \mathrm{SO}_{x}\right)$ and the particulate matter $\left(\mathrm{PM}_{2.5}, \mathrm{PM}_{\text {coarse }}\right)$ were used. The data were temporally disaggregated into hourly emissions according to the SNAP sectors, the country codes and the 
time factors from the GENEMIS project (Friedrich and Reis 2004; Tuccella et al. 2012). Other converting steps were the vertical disaggregation into the lowest six model layers, the spatial conversion with the inverse next neighbor method and the chemical species disaggregation from the EMEP system into the used CBMZ system. A more detailed description of these processing steps can be found in Ritter (2009).

Biogenic emissions are built up on runtime using the model of emissions of gases and aerosols from nature (MEGAN version 2.0.4) (Guenther et al. 2006; Sakulyanontvittaya et al. 2008). The online implementation of the MEGAN emissions are slightly simplified in comparison to the standalone version. Only for isoprene emissions a separate map of emission factors is used. All other ones are assigned an emission factor based on the plant functional type. Also no soil moisture factor and no production and loss of emissions within the plant canopy are applied as no explicit canopy model is used.

\subsection{Chemical boundary conditions}

The effect of two different chemical boundary conditions on the European domain was evaluated against each other. The first one is hardcoded in the WRF-Chem model. The values are based on an idealized, northern hemispheric, mid-latitude, clean environmental, vertical profile from the NOAA Aeronomy Lab Regional Oxidant Model (NALROM) (McKeen et al. 1991; Liu et al. 1996; Peckham et al. 2010). This profile is declared globally so that lateral boundary conditions can be derived. Chemical initial conditions are not needed when a spin-up calculation of 5 days precedes. Consequent runs can be initialized by their already calculated chemical fields.

On the other hand, monthly mean values (1997-2001) of the global LMDZ-INCA model were implemented (Hauglustaine et al. 2004; Szopa et al. 2009) as chemical boundary conditions. This model is a coupled chemistry and aerosol model with a horizontal resolution of $3.75^{\circ} \times 2.5^{\circ}$. The weighted mean of the surrounding eight grid points (3D) is calculated for every boundary grid point of the European domain. This procedure was applied for eight different chemical species $\left(\mathrm{O}_{3}, \mathrm{NO}, \mathrm{NO}_{2}, \mathrm{HNO}_{3}\right.$, PAN, $\mathrm{H}_{2} \mathrm{O}_{2}, \mathrm{CO}, \mathrm{HCHO}$ ). For all other chemical species the hardcoded values were taken as boundary conditions.

\subsection{Meteorological input parameters}

Two different meteorological input parameters were used for this study and their effect on the domain has been compared. The meteorological input parameters were newly initialized every five simulated days with an additional spin-off time of $12 \mathrm{~h}$. This leads to a 5.5-day forecast, where the first $12 \mathrm{~h}$ where skipped to minimize the differences between the small scale features within the domain and the large scale features from the meteorological input datasets. The first ones are datasets of the Global Forecast System (GFS) that is available from NOAA. The horizontal resolution of the gridded dataset is $1.0^{\circ}$ (original spectral grid: T382L64) for July 2005 and is available in $3 \mathrm{~h}$ steps. Only the initial and first forecast step were used to stay as close as possible to observations. Data is available online from February 2005 onwards.

Because the overall aim is to simulate the years 1991 and 2002 other meteorological input datasets namely Reanalysis data from NCEP were used. These datasets are continually gridded and incorporate observations and numerical weather prediction model output and date back to 1948. However, revised Reanalysis data (Reanalysis II) are available from 1979 onwards with a horizontal resolution of $2.5^{\circ}$ (original spectral grid: T62L28) for $6 \mathrm{~h}$ timesteps (Kanamitsu et al. 2002). For this study the revised Reanalysis II data were compared to the GFS data to evaluate how and to what extent the two different datasets influence modeled air pollutants within WRFChem.

\subsection{European measurements}

The validation of the model results was done with data from the EMEP Measurement Network for $\mathrm{O}_{3}, \mathrm{SO}_{2}, \mathrm{NO}_{2}$, $\mathrm{PM}_{10}$ and $\mathrm{PM}_{2.5}$ (EMEP 2010). All EMEP stations are ground-based and classified as rural and additionally only stations with a fixed minimum distance to the boundaries were considered to eliminate artifacts from boundary conditions. Overall around $100 \mathrm{O}_{3}, 40 \mathrm{SO}_{2}, 30 \mathrm{NO}_{2}$ and $\mathrm{PM}_{10}$ and $17 \mathrm{PM}_{2.5}$ stations could be used for the verification (see Fig. 1). $\mathrm{PM}_{2.5}$ measurements were done at the same location as some $\mathrm{PM}_{10}$ measurements and therefore not shown in Fig. 1. The validation for $\mathrm{SO}_{2}$ was not taken into account, because $\mathrm{SO}_{2}$ concentrations for the European domain are very low and of little interest for the overall study.

\subsection{Statistical indicators}

There are a number of statistical parameters that can be used to validate model output. This study focused on the Pearson correlation coefficient, the mean bias, the root mean square error and the mean absolute gross error. These parameters were often used and suggested in various scientific literature (deMeij et al. 2009; Seinfeld and Pandis 2006; Jacobson 2005). 


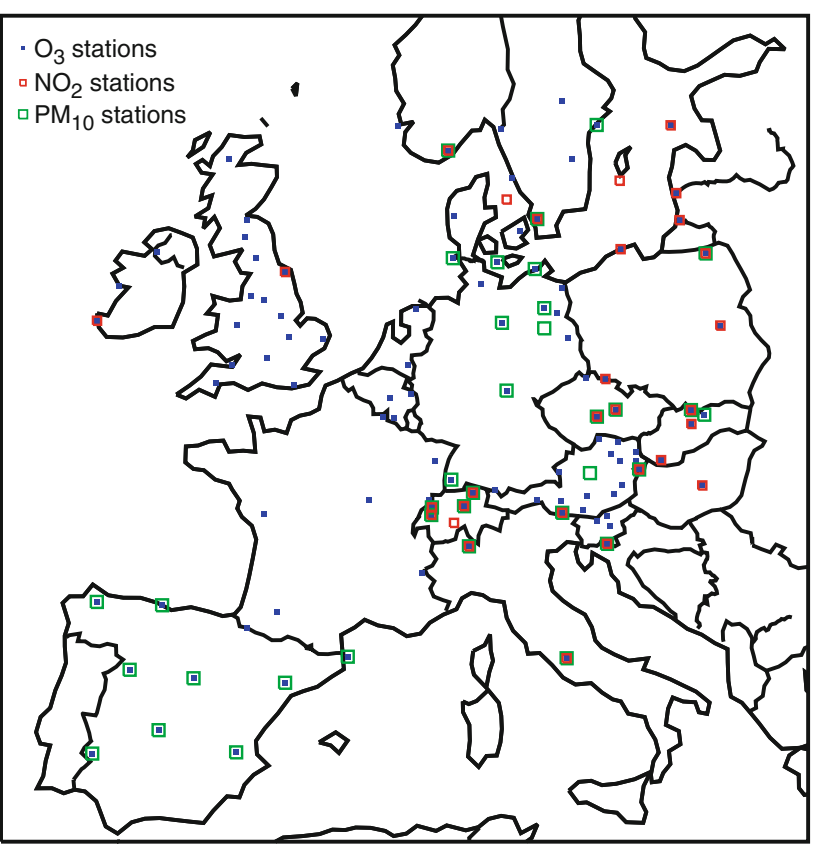

Fig. 1 EMEP measurement stations $\left(\mathrm{O}_{3}, \mathrm{NO}_{2}\right.$ and $\left.\mathrm{PM}_{10}\right)$ with valid data for the modeled time period (July 2005)

\section{Results}

\subsection{Chemical boundary conditions}

We compared the influence of different chemical boundary conditions (LMDZ-INCA vs. idealized profiles) on WRFChem (meteorological initialization with GFS). Fig. 2 shows the mean difference (LMDZ-INCA minus NALROM) of ground-level ozone for these two runs for July 2005 and the corresponding scatterplot with the LMDZINCA-based runs on the $x$ axis and the NALROM-based runs on the $y$ axis. Almost over the whole domain we see a positive mean difference up to $25 \mu \mathrm{g} / \mathrm{m}^{3}$. Only over the north-western part of the domain (Atlantic Ocean) we notice negative differences of ozone concentration up to $12 \mu \mathrm{g} / \mathrm{m}^{3}$. A big distinction between the two chemical boundary conditions is the availability of spatial data (LMDZ-INCA) versus only a globally applied, vertical profile (NALROM). Figure 3 shows the monthly mean July concentrations (1997-2001) for ground-based ozone from the LMDZ-INCA model for the European domain. The standardized profile (NALROM) has a concentration of $0.03 \mathrm{ppmv}$ (around $60 \mu \mathrm{g} / \mathrm{m}^{3}$ ) for ground-level ozone at standard atmospheric pressure. With a special focus on the borders of this figure (boundary conditions) we observe significant higher ozone concentrations over land-based pixels compared to the $60 \mu \mathrm{g} / \mathrm{m}^{3}$ and in contrast lower concentrations over the Atlantic Ocean. The distribution of ozone concentrations at the boundaries of Fig. 3 explains the differences of the model output initialized by the standardized profile and the LMDZ-INCA model. A correlation of 0.90 between the runs initialized by LMDZINCA and NALROM is achieved. If we subtract $300 \mathrm{~km}$ of each boundary (equals $10 \%$ on each side) the correlation slightly goes up to 0.93 (rmse $=2.00$, mage $=0.33$, bias $=$ 0.28). Table 1 indicates the statistical values of the two runs (NALROM + GFS and LMDZ-INCA + GFS) compared to ozone EMEP measurements. Chemical boundaries derived from the LMDZ-INCA model perform better than the standardized profiles in terms of the ozone results of WRF-Chem. We can observe this fact in the Pearson correlation coefficient for the hourly data comparison $(0.63 \mathrm{vs}$. $0.60)$, the daily mean values ( 0.67 vs. 0.62$)$ and the daily maxima values (0.72 vs. 0.64 ) for the LMDZ-INCA initialized run and the NALROM initialized run, respectively.

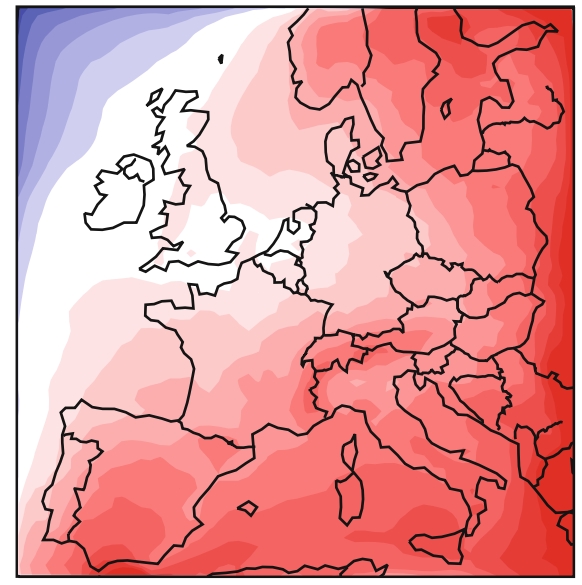

Fig. 2 Map (left) and scatterplot (right) of the mean difference of ground-level ozone $\left(\mathrm{O}_{3}\right)$ simulated for July 2005 with WRF-Chem driven by monthly mean values from the LMDZ-INCA model minus

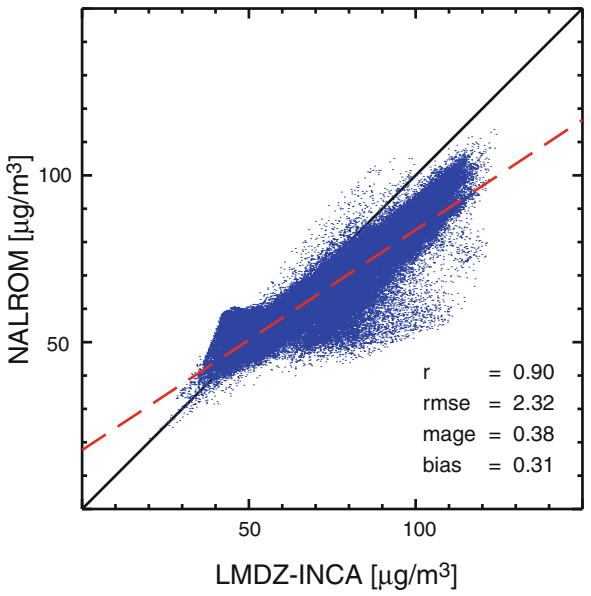

WRF-Chem driven by standardized profiles obtained from the NALROM model as chemical boundary conditions 


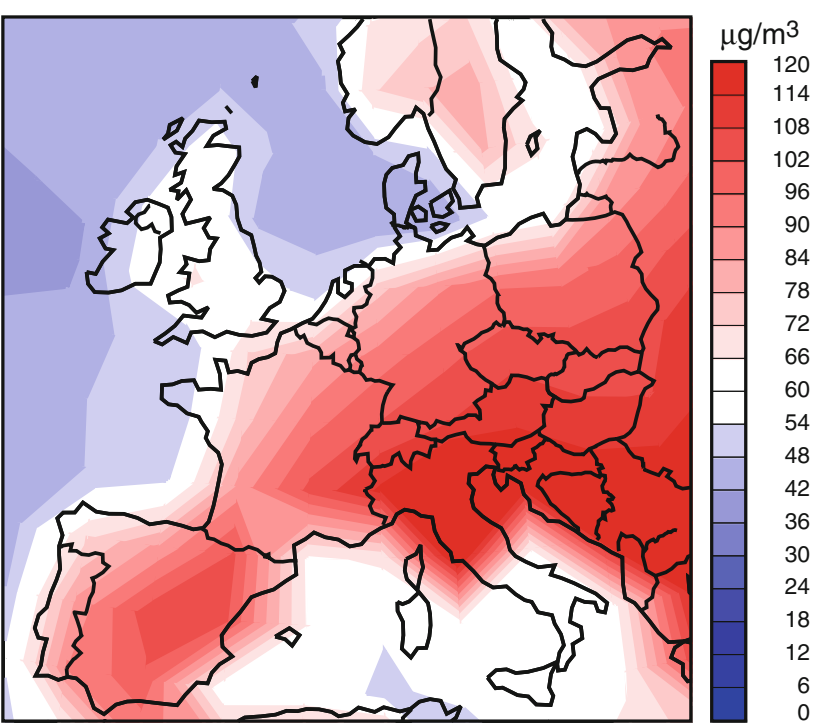

Fig. 3 Monthly mean values for July (1997-2001) of ground-level ozone $\left(\mathrm{O}_{3}\right)$ from the LMDZ-INCA model

Other than the standardized profile the LMDZ-INCA model represents the tropopause with very high ozone concentrations in the stratosphere. Therefore, huge differences in ozone concentrations can be found in upper levels between these two runs. Already from $800 \mathrm{hPa}$ on only positive mean difference can be found in favor of the model output initialized by LMDZ-INCA. As the overall aim of this study is to compare air pollutants on health effects, we will furthermore focus on ground-based results.

The same comparison of the effect of the two different chemical boundary conditions on WRF-Chem was made for $\mathrm{NO}_{2}$ (Fig. 4), $\mathrm{PM}_{10}$ and $\mathrm{PM}_{2.5}$. Boundary pixels for $\mathrm{NO}_{2}$ at ground level derived from the LMDZ-INCA model have a range of approx. $0.003-3.5 \mu \mathrm{g} / \mathrm{m}^{3}$ whereas the standardized NALROM profile has a value of approx. $0.03 \mu \mathrm{g} / \mathrm{m}^{3}$. In the middle and upper troposphere the concentrations are roughly the same. Almost no influence on the mean difference of the two modeled runs can be seen in Fig. 4. Only over the southern part of the North Sea and at the boundaries some regions with positive differences can be found. These differences never exceed more than $0.8 \mu \mathrm{g} / \mathrm{m}^{3}$ and the Pearson correlation coefficient tends to 1.00. As $\mathrm{PM}_{10}$ and $\mathrm{PM}_{2.5}$ simulations were absent in the LMDZ-INCA model, the same boundary values were applied as the ones from the standardized profile. Pearson correlation coefficient tends to 1.00 for $\mathrm{PM}_{10}$ as well as for $\mathrm{PM}_{2.5}$. Therefore, the figures are not shown in this paper. However, there are marginal differences of up to $1 \mu \mathrm{g} / \mathrm{m}^{3}$ for $\mathrm{PM}_{10}$. Nitric acid $\left(\mathrm{HNO}_{3}\right)$ is available by the LMDZINCA model which can react as precursor for particulate matter. How far this contributes to the differences could not be evaluated in this study.

\subsection{Meteorological initial and boundary conditions}

The influence of different meteorological initial and boundary conditions (GFS and Reanalysis II) on ozone concentrations of WRF-Chem (LMDZ-INCA as chemical boundary conditions) are shown in Fig. 5. These options were tested due to the absence of GFS data for the intended years of the overall study (1991 and 2002). The map shows the mean differences in $\mu \mathrm{g} / \mathrm{m}^{3}$ of ozone for July 2005 (GFS minus Reanalysis II). The values rarely exceed a difference of more than $5 \mu \mathrm{g} / \mathrm{m}^{3}$ in the center of the domain. These small differences already occurred at the first modeled time step and are transported along with the wind at roughly the same directions for both different runs. Summarized over the entire month land-based pixels show rather a positive difference and water pixels rather a negative one. The scatterplot on the right side of Fig. 5 represents WRFChem initialized by the GFS ( $x$ axis) and Reanalysis II ( $y$ axis) data. Overall a correlation of 0.96 is achieved, which leads to the assumption that we can use the Reanalysis II data for the overall study without any concerns regarding ozone. Despite the larger discrepancies near the eastern boundaries and especially near the south of Spain the statistical values remain exactly the same if we subtract $300 \mathrm{~km}$ from each side of the domain for the analysis. However, the difference near the south of Spain can be explained by a difference in near-surface
Table 1 Comparison of the statistical values for ozone (July 2005) at the EMEP

measurements and ozone computed with WRF-Chem initialized by different chemical and meteorological boundary and initial conditions

\begin{tabular}{llrrrr}
\hline Frequency & IC/BC & \multicolumn{1}{l}{ Bias } & Mage & rmse & $r$ \\
\hline $\mathrm{O}_{3}$ hourly values & NALROM + GFS & -10.11 & 20.65 & 26.84 & 0.60 \\
& LMDZ-INCA + GFS & -3.15 & 18.53 & 24.13 & 0.63 \\
& LMDZ-INCA + R2 & -3.81 & 18.82 & 24.52 & 0.62 \\
$\mathrm{O}_{3}$ daily means & NALROM + GFS & -10.19 & 16.15 & 21.57 & 0.62 \\
& LMDZ-INCA + GFS & -3.24 & 13.83 & 17.99 & 0.67 \\
& LMDZ-INCA + R2 & -3.90 & 14.11 & 18.41 & 0.66 \\
$\mathrm{O}_{3}$ daily maxima & NALROM + GFS & -19.19 & 23.23 & 30.09 & 0.64 \\
& LMDZ-INCA + GFS & -11.33 & 18.04 & 23.87 & 0.72 \\
& LMDZ-INCA + R2 & -12.34 & 18.81 & 24.74 & 0.70 \\
\hline
\end{tabular}



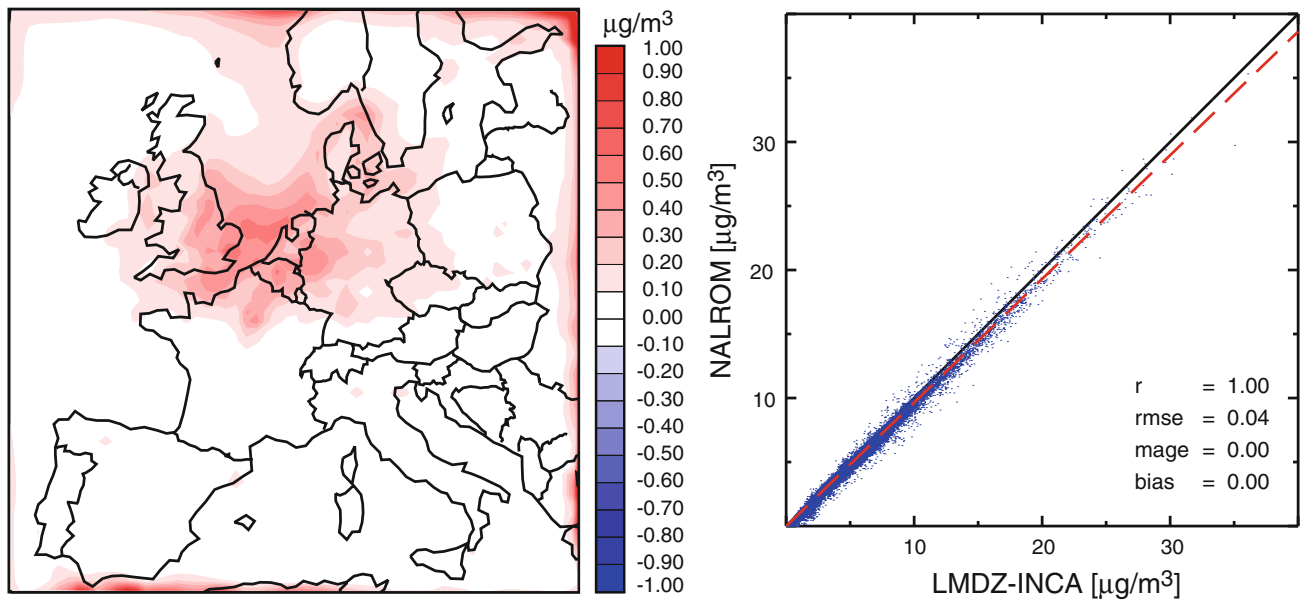

Fig. 4 Map (left) and scatterplot (right) of the mean difference of ground-level nitrogen dioxide $\left(\mathrm{NO}_{2}\right)$ simulated for July 2005 with WRF-Chem driven by monthly mean values from the LMDZ-INCA model minus WRF-Chem driven by standardized profiles obtained from the NALROM model as chemical boundary conditions

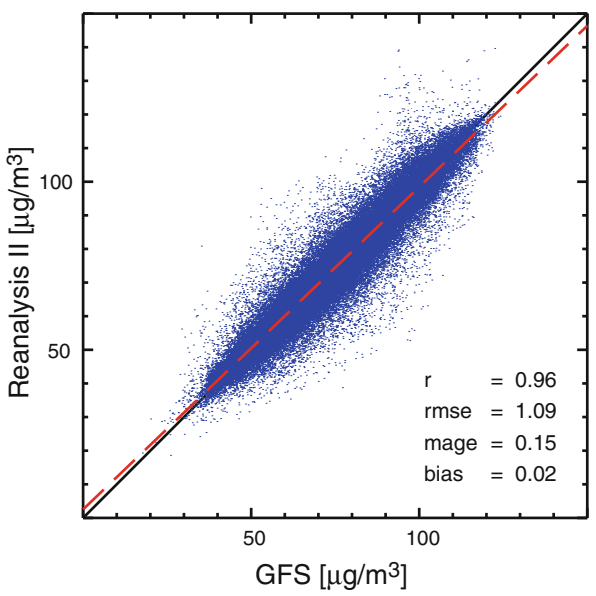

Fig. 5 Map (left) and scatterplot (right) of the mean difference of ground-level ozone $\left(\mathrm{O}_{3}\right)$ simulated for July 2005 with WRF-Chem initialized by GFS data minus WRF-Chem initialized by Reanalysis II meteorological data

temperature of up to $5 \mathrm{~K}$ in the same region when the model was initialized by Reanalysis II instead of GFS. All other differences can neither be explained by differences in temperature nor solar radiation. Compared to the EMEP measurements the model output initialized by the GFS model performed slightly better (see Table 1 ) for ozone. The Pearson correlation coefficient for the hourly data, daily mean and daily maxima of $\mathrm{O}_{3}$ were $0.63,0.67$ and 0.72 for the GFS model output and $0.62,0.66,0.70$ for the Reanalysis II model output.

The two meteorological input parameters were also tested for $\mathrm{NO}_{2}, \mathrm{PM}_{10}$ and $\mathrm{PM}_{2.5}$, whereas the latter one is not presented in this paper due to its similarity to $\mathrm{PM}_{10}$. $\mathrm{NO}_{2}$ differences of the two runs initialized by GFS and Reanalysis II occur near coastal regions, over land, at the southern boundaries and particularly between the area of southern England and the Netherlands (see Fig. 6). Likewise for $\mathrm{O}_{3}$, the differences in the center of the domain are mainly caused by the meteorological initial parameters and the ones at the boundaries mainly by the boundary conditions. The coastal and boundary differences can be explained with the higher resolution of GFS and its better representation of the meteorological (especially over the coastal and boundary regions). The mean differences (positive and negative) of more than $1 \mu \mathrm{g} / \mathrm{m}^{3} \mathrm{NO}_{2}$ in the area of southern England and the Netherlands over the whole July 2005 were due to several anticyclone systems that were not properly captured with either the GFS or the Reanalysis II dataset. Nevertheless, a Pearson correlation coefficient of 0.96 between these two runs could be achieved. For $\mathrm{PM}_{10}$ only a Pearson correlation coefficient of $0.90\left(\mathrm{PM}_{2.5}: 0.89\right)$ has been obtained. The points of the 
scatterplot (Fig. 7) disperse a lot more and on the map are larger regions with higher differences between the two runs initialized by GFS and Reanalysis II. There is no clear pattern as it can be seen for $\mathrm{O}_{3}$ or $\mathrm{NO}_{2}$ and the differences cannot be explained by looking at the distribution or the differences of near-surface temperature and solar radiation. The differences occur from the first timestep on but increase during the run, so that the boundary conditions seem to have a bigger influence as for the other two pollutants.

\subsection{Evaluation with measurements}

In Fig. 8a-d, hourly mean values of all available EMEP measurement stations and the mean of their corresponding grid points can be seen for July 2005. The results were obtained using the LMDZ-INCA model as chemical boundary conditions and the GFS model as meteorological initial and boundary conditions. For ozone good correlation exists (part A), also due to its dependency on meteorological parameters (e.g. temperature and solar radiation). Part $\mathrm{B}$ shows $\mathrm{NO}_{2}$ with the additional line being the daily average of the hourly model output data for a better comparison as $\mathrm{NO}_{2}$ stations were only available as daily values. WRF-Chem simulates too low concentrations over the entire month but is still within a satisfying range if we take into account that the horizontal resolution is $50 \mathrm{~km}$ with EMEP stations classified as rural. Trends can more or less be captured by the model. Part $\mathrm{C}$ and $\mathrm{D}$ show particulate matter $\left(\mathrm{PM}_{10}\right.$ and $\left.\mathrm{PM}_{2.5}\right)$ also with an additional line as modeled daily mean values. Both modeled pollutants have a similar trend as well as the corresponding observations.
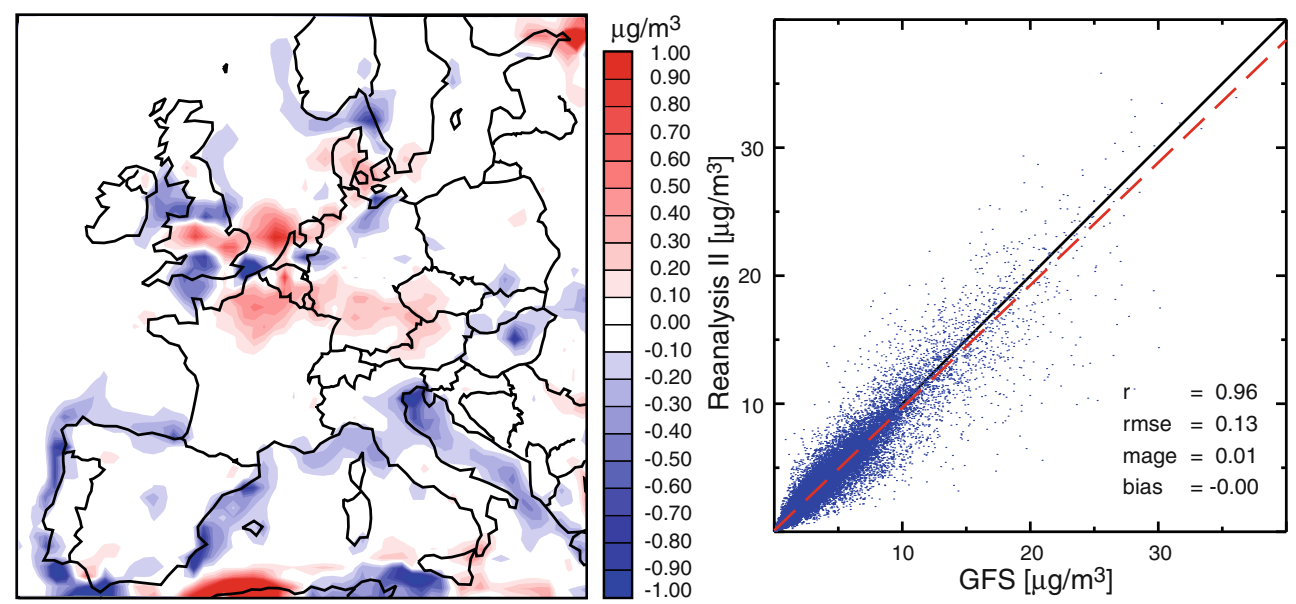

Fig. 6 Map (left) and scatterplot (right) of the mean difference of ground-level nitrogen dioxide $\left(\mathrm{NO}_{2}\right)$ simulated for July 2005 with WRF-Chem initialized by GFS data minus WRF-Chem initialized by Reanalysis II meteorological data
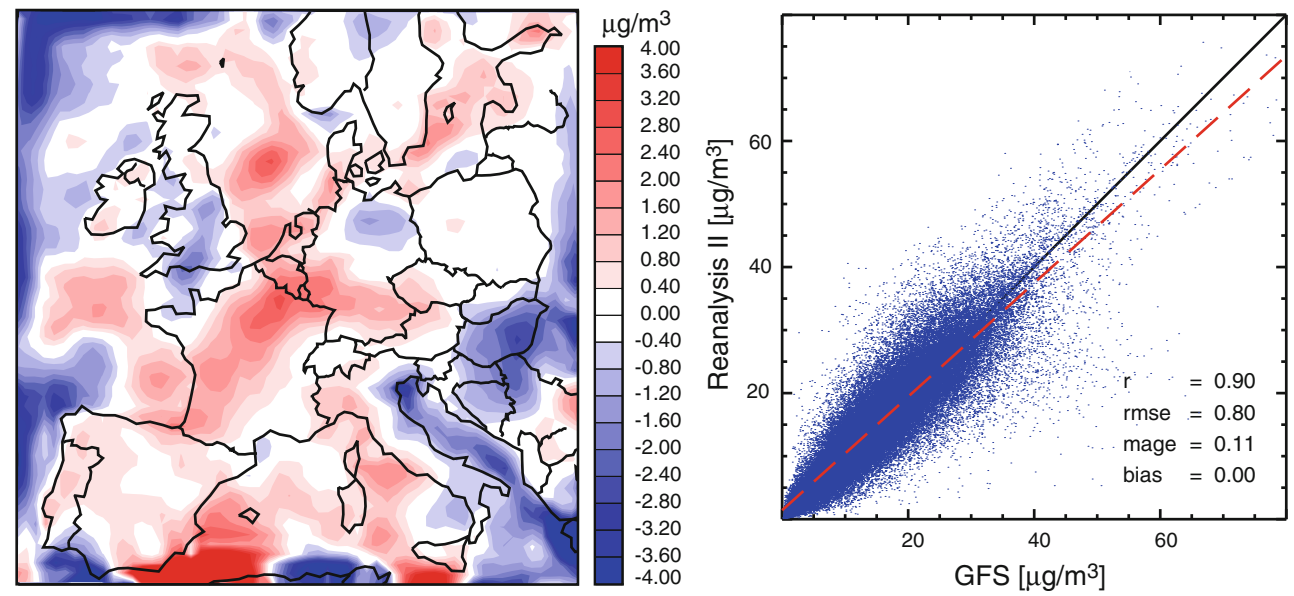

Fig. 7 Map (left) and scatterplot (right) of the mean difference of ground-level particulate matter (PM 10 ) simulated for July 2005 with WRF-Chem initialized by GFS data minus WRF-Chem initialized by Reanalysis II meteorological data 
Fig. 8 Mean of EMEP measurements and mean of their corresponding model grid points of WRF-Chem (hourly and daily values) for July 2005 . a $\mathrm{O}_{3}, \mathbf{b} \mathrm{NO}_{2}, \mathbf{c} \mathrm{PM}_{10}$ and $\mathbf{d} \mathrm{PM}_{2.5}$
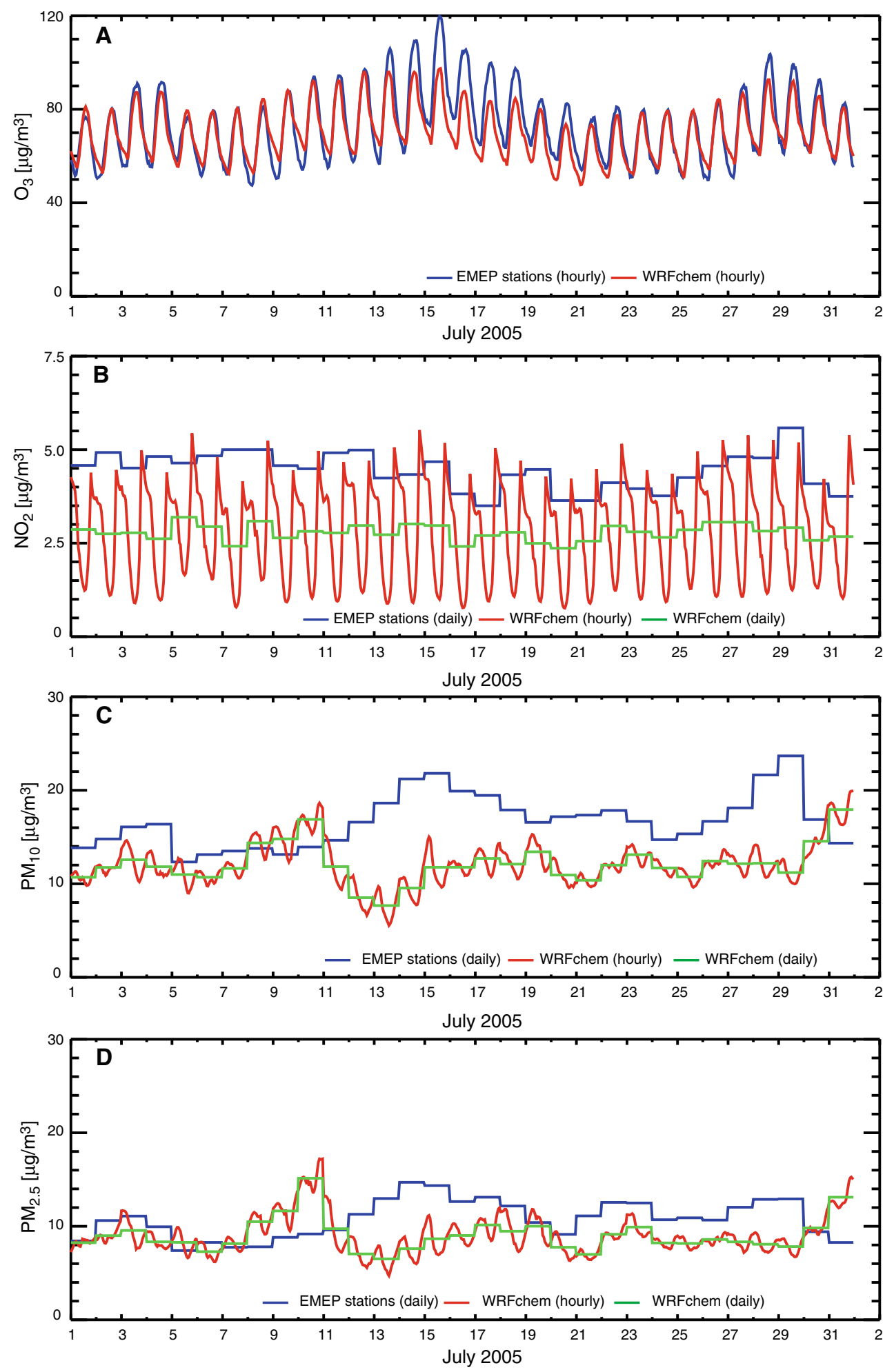

Nevertheless, the trends have a smaller overall amplitude for modeled and measured data for $\mathrm{PM}_{2.5}$ compared to $\mathrm{PM}_{10}$. Both pollutants have periods of similar and controversial trends between the model output and the observations. We could not find any patterns for the near-surface temperature or solar radiation that could explain these differences between the model and the measurements. The differences are sometimes more than $25 \mu \mathrm{g} / \mathrm{m}^{3}$ between a single station (especially some stations in Spain) and the corresponding modeled grid point. The meteorological conditions during the modeled month (July 2005) caused severe droughts in Spain, Portugal and southern France and 

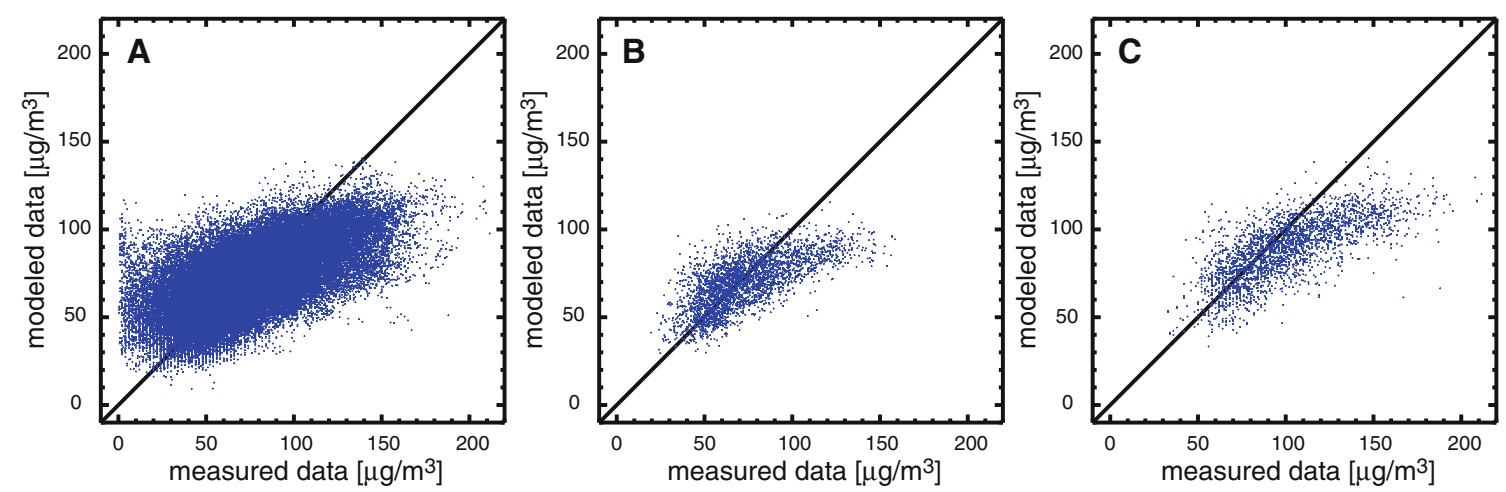

Fig. 9 Scatterplots for $\mathrm{O}_{3}$ hourly values (a), $\mathrm{O}_{3}$ daily mean (b) and $\mathrm{O}_{3}$ daily maxima (c) for July 2005. Illustrated are EMEP measurements $(x$ axis) against their corresponding grid points of the WRF-Chem output ( $y$ axis)

wildfires in Spain. How far these wildfires contributed to the $\mathrm{PM}_{10}$ concentrations or the differences between the model and the EMEP stations could not be shown in this study.

For ozone further analysis was done as hourly observations were available. Scatterplots for hourly data, daily mean and daily maxima are illustrated in Fig. 9a-c. The measured data forms the $x$ axis and the modeled data the $y$ axis (LMDZINCA and GFS as boundary and initial condition). Corresponding statistical parameters are listed in Table 1. Every available hourly data of all EMEP measurements were statistically analysed (over 100). The Pearson correlation coefficient increases from 0.63 to 0.67 and 0.72 for hourly data, daily means and daily maxima, respectively.

\section{Discussion}

The sensitivity test for the different chemical boundary conditions showed that there are differences between the two runs concerning ozone. The differences of up to $60 \mu \mathrm{g} / \mathrm{m}^{3}$ between the different boundary conditions are decreased after the calculations. Only a small region over the Atlantic Ocean has a negative difference between the two runs but also these negative differences disappear from $800 \mathrm{hPa}$ on upwards. The use of spatially varying chemical boundary conditions (e.g. LMDZ-INCA) with its representation of the tropopause increased the performance of WRF-Chem as the model fitted better with EMEP measurements. Nevertheless, the influence of different chemical boundary conditions on other pollutants (e.g. $\mathrm{NO}_{2}, \mathrm{PM}_{10}$ and $\mathrm{PM}_{2.5}$ ) seems negligible as Pearson correlation coefficients of 1.00 were achieved between the two different initialized runs. For $\mathrm{PM}_{10}$ this is not surprising as data is not available in the LMDZ-INCA model and the same values from the standardized profile were taken. Also for $\mathrm{NO}_{2}$ the differences between the two runs are minor. The standardized profile has a concentration around $0.03 \mu \mathrm{g} / \mathrm{m}^{3}$ for ground-level $\mathrm{NO}_{2}$ whereas the LMDZ-INCA values vary between 0.003 and $3.5 \mu \mathrm{g} / \mathrm{m}^{3}$ at the boundaries of the domain. The chemical boundary conditions do not have a strong impact on $\mathrm{NO}_{2}$ concentrations as the anthropogenic emissions dominate. According to Szopa et al. (2009) better results compared to measurements could be possible with more refined, daily chemical boundary conditions, especially for regions near the boundaries.

The comparison of the use of different meteorological initial and boundary conditions revealed minor mean differences for ozone and $\mathrm{NO}_{2}$. All the graphs shown in this paper exclude a spin-off time from June 26th to 30th. However, already these spin-off days showed almost the same difference as the mean concentrations of July. Therefore, the differences for $\mathrm{O}_{3}$ and $\mathrm{NO}_{2}$ are mostly due to the initial field and not due to the meteorological boundary parameters. The minor discrepancies between the runs are probably caused by the different horizontal resolutions or anticyclone systems that were not correctly represented within one of the two meteorological datasets. For these two pollutants $\left(\mathrm{O}_{3}\right.$ and $\left.\mathrm{NO}_{2}\right)$ the decrease in accuracy of the model is small and Reanalysis II data can be used for the European domain without any concern. However, the Pearson correlation coefficient for particulate matter was only 0.90 (between the two different runs) and differences up to $5 \mu \mathrm{g} / \mathrm{m}^{3}$ exist at the boundary regions of the domain. Therefore, the use of different meteorological input parameters leads to a change in $\mathrm{PM}_{10}$ concentration. The statistical parameters for $\mathrm{O}_{3}, \mathrm{NO}_{2}$ and $\mathrm{PM}_{10}$ did not change with the exclusion of the boundaries of the domain in the analysis. Overall, GFS data should be preferred over Reanalysis II datasets when possible. On the one hand, the correlations of air pollutants to EMEP measurement stations were slightly better when WRF-Chem was initialized by GFS (see Table 1 for $\mathrm{O}_{3}$ ) and on the other hand, the meteorological parameters (e.g. temperature) also achieved better correlations compared to weather stations. Commonly, more often updated meteorological boundary 
conditions ( $3 \mathrm{~h}$ for GFS instead of $6 \mathrm{~h}$ for Reanalysis II) are more suitable for limited domains.

Regarding the comparison of the results to measurements, the model performs well for ozone. The diurnal cycle is well represented and trends are captured by WRFChem. For $\mathrm{NO}_{2}$ some of the trends can be represented by the model (e.g. July 20th-26th in Fig. 8b). On the other hand, during the entire month, the concentrations were underestimated with absolute difference between 1 and $3 \mu \mathrm{g} / \mathrm{m}^{3}$. Due to its dependencies on a variety of parameters, $\mathrm{PM}_{10}$ seems to be difficult to model over a longer period. The first days are in good agreement with measured data (e.g. July 1st-11th in Fig. 8c), but afterwards contrasting trends are observed even though the values of the modeled $\mathrm{PM}_{10}$ are within an acceptable range. We further looked at meteorological parameters to find an explanation for the contrasting trends but neither temperature, solar radiation nor wind speed could explain the trends. When we looked at individual stations and their corresponding modeled grid point we see that not all stations have these controversial trends. On the other hand, big differences between model and observation can be found for some stations in Spain. How far for example wildfires contribute to these differences, cannot be shown in this study. The same facts can be observed for $\mathrm{PM}_{2.5}$ but with lower absolute differences between the model and the measurements. Trends seem to be identical for particles smaller than 10 and $2.5 \mu \mathrm{m}$. According to Seinfeld and Pandis (2006) and Hallquist et al. (2009), the implementation of an additional secondary organic aerosol module (e.g. Schell et al. 2001) would have significant influence on concentrations of particulate matter. The constant factors for splitting $\mathrm{PM}_{2.5}$ and $\mathrm{PM}_{\text {coarse }}$ emissions into aerosol components (elemental carbon, organic aerosol, sulfate, nitrate and undefined mass) and different sizes (Aitken and accumulation mode for $\mathrm{PM}_{2.5}$ and afterwards the 4 different bins) also have an impact on particle concentrations. Furthermore, the number of EMEP measurement stations (approx. 30 for $\mathrm{PM}_{10}$ and $\mathrm{NO}_{2}$ ) and their location could have an influence on the comparison. Even though all EMEP stations are classified as rural, it is not always selfevident that one station can correctly represent an area of $50 \mathrm{~km} \times 50 \mathrm{~km}$. This issue is exacerbated when the altitude difference of the station and the corresponding grid point increases. On the other hand, an accumulation of stations within a small region leads to an overweighing of some region (e.g. Switzerland, Austria, United Kingdom).

A good overview of the performance of other air quality models over Europe and their statistical values can be found in Pay et al. (2010) and more detailed model performance statistics for some models in van Loon et al. (2004, 2007). The range of the correlation factors for most of the studies in the aforementioned papers is within
$0.55-0.8$ for ozone daily averages and $0.69-0.84$ for daily peak values. We have to take into account that this paper only presented the output of July 2005 and not an entire year. The data in van Loon et al. (2007) are, in addition to being presented as annual statistical values, also summarized into seasonal data. With regard to the differences of seasonal and monthly data, we tried to compare the Pearson correlation coefficient of this paper with the seasonal ones from van Loon et al. (2007). For daily average WRFChem (0.67) performed better than all the other mentioned models $(0.35-0.64)$ and only slightly worse than their ensemble (0.68). Daily maxima values for the models in van Loon et al. (2007) are between 0.51 and 0.77 and the ensemble is 0.78. Only the CHIMERE model and the ensemble performed slightly better than WRF-Chem in this paper. We have to mention that the models used in van Loon et al. (2007) were compared to a reduced set of stations in order to prevent overweighing of some regions with a large number of stations and only stations below an altitude of $1,000 \mathrm{~m}$ were considered. We also tested the performance of WRF-Chem compared to stations only below a certain altitude but there were no significant changes so that we preferred to keep as much stations as possible for the comparison.

\section{Conclusions}

This paper presented the influence of different chemical and meteorological boundary and initial conditions on air pollutants and their comparison to EMEP measurements. Chemical boundary conditions have mainly an influence on ozone and meteorological initial and boundary conditions have the biggest impact on particulate matter. The Pearson correlation coefficients range from 0.90 to 1.00 . The monthly mean values driven by the LMDZ-INCA model performed better than the time invariant standardized profile compared to measurements. The influence of meteorological initial and boundary conditions on ozone concentrations was not as significant as the chemical boundary conditions but still noticeable. For $\mathrm{NO}_{2}$ the differences between the two runs were rather small. A noticeable impact on the two runs with different meteorological input parameters is found for particulate matter. Nevertheless, summarized over the entire European domain, the NCEP Reanalysis II data produced satisfying results even though the GFS model with the higher resolution leads to slightly better results. Whenever possible GFS data should be preferred as meteorological input parameters, especially for regional domains. For the years before 2004, Reanalysis II data are a good alternative to initialize WRF-Chem. The European simulations show good results for observed air pollutants, with ozone being 
the most and $\mathrm{PM}_{10}$ being the least satisfying. In comparison to statistical values of other models used over Europe for ozone, WRF-Chem shows encouraging results. The flexibility of WRF-Chem with its modular design allows the user to implement different chemical options and to test them easily. Improvements in the model output could probably be achieved with more detailed daily chemical boundary conditions, more refined chemical species conversion, a better horizontal and vertical resolution and/or more detailed anthropogenic emissions. If more rural measurement stations for other air pollutants in addition to ozone existed (in particular, hourly measurements), a better validation could be made. To conclude, WRF-Chem performed best with spatially resolved chemical boundary conditions and high resolution meteorological input parameters. The model performed satisfyingly for observed pollutants and is within the top air quality models.

Acknowledgments This study was supported by the Swiss National Science Foundation and is part of the SAPALDIA study. Further supporters are the Federal Office for Forest, Environment and Landscape; the Federal Office of Public Health; the Federal Office of Roads and Transport; the cantons government of Aargau, Basel-Stadt, Basel-Land, Geneva, Luzern, Ticino, and Zurich; the Swiss Lung League; the Lung Leagues of Basel-Stadt/Basel-Landschaft, Geneva, Ticino, and Zurich. The work has been performed under the HPCEUROPA2 project (project number: 228398) with the support of the European Commission-Capacities Area-Research Infrastructures. Data from the GENEMIS project coordinated by the Institute of Energy Economics and the Rational Use of Energy (IER) at the University of Stuttgart have been used.

\section{References}

Ackermann-Liebrich U, Leuenberger P, Schwartz J, Schindler C, Monn C, Bolognini G, Bongard JP, Brändli O, Domenighetti G, Elsasser S, Grize L, Karrer W, Keller R, Keller-Wossidlo H, Künzli N, Martin BW, Medici RC, Perruchoud AP, Schöni MH, Tschopp JM, Villiger B, Wüthrich B, Zellweger JP, Zemp E, SAPALDIA team (1997) Lung function and long term exposure to air pollutants in Switzerland. Am J Respir Crit Care Med 155:122-129

Ackermann-Liebrich U, Kuna-Dibbert B, Probst-Hensch NM, Schindler C, Felber Dietrich D, Stutz EZ, Bayer-Oglesby L, Baum F, Brändli O, Downs SH, Keidel D, Gerbase MW, Imboden M, Keller R, Knöpfli B, Künzli N, Nicod L, Staedele P, Tschopp JM, Zellweger JP, Leuenberger P, SAPALDIA team (2005) Follow-up of the Swiss Cohort study on air pollution and lung diseases in adults (SAPALDIA 2) 1991-2003: methods and characterization of participants. Soz Praventivmed 50(4):245-263

Baldasano JM, Jiménez-Guerrero P, Jorba O, Pérez C, López E, Güereca P, Martín F, Vivanco MG, Palomino I, Querol X, Pandolfi M, Sanz MJ, Diéguez JJ (2008) Caliope: an operational air quality forecasting system for the Iberian Peninsula, Balearic Islands and Canary Islands-first annual evaluation and ongoing developments. Adv Sci Res 2:89-98

Bellander T, Berglind N, Gustavsson P, Jonson T, Nyberg F, Pershagen G, Järup L (2001) Using geographic information systems to assess individual historical exposure to air pollution from traffic and house heating in Stockholm. Environ Health Perspect 109:633-639
Bessagnet B, Hodzic A, Vautard R, Beekmann M, Cheinet S, Honoré C, Liousse C, Rouil L (2004) Aerosol modeling with CHIMERE: preliminary evaluation at the continental scale. Atmos Environ 38:2830-2817

Chen F, Dudhia J (2001) Coupling and advanced land surfacehydrology model with the Penn State-NCAR MM5 modeling system. Part I: model implementation and sensitivity. Mon Weather Rev 129:569-585

Cohen MA, Adar SD, Allen RW, Avol E, Curl CL, Gould T, Hardie D, Ho A, Kinney P, Larson TV, Sampson P, Sheppard L, Stukovsky KD, Swan SS, Liu SLJ, Kaufman JD (2009) Approach to estimating participant pollutant exposures in the multi-ethnic study of atherosclerosis and air pollution (MESA Air). Environ Sci Technol 43:4687-4693

de Meij A, Gzella A, Cuvelier C, Thunis P, Bessagnet B, Vinuesa JF, Menut L, Kelder HM (2009) The impact of MM5 and WRF meteorology over complex terrain on CHIMERE model calculations. Atmos Chem Phys 9:6611-6632

Dudhia J (1989) Numerical study of convection observed during the winter monsoon experiment using a mesoscale two-dimensional model. J Atmos Sci 46:3077-3107

EMEP (2010) EMEP measurement data online. URL http://tarantula. nilu.no/projects/ccc/emepdata.html

Fast JD, Gustafson WI, Easter RC, Zaveri RA, Barnard JC, Chapman EG, Grell GA, Peckham SE (2006) Evolution of ozone, particulates, and aerosol direct radiative forcing in the vicinity of Houston using a fully coupled meteorology-chemistry-aerosol model. J Geophys Res [Atmos] 111:D21305

Friedrich R, Reis S (eds) (2004) Emissions of air pollutants. Measurements, calculations and uncertainties. Springer, Berlin

Grell G, Peckham S, Schmitz R, McKeen S, Frost G, Skamarock W, Eder B (2005) Fully coupled online chemistry within the WRF model. Atmos Environ 39:6957-6975

Grell GA, Emeis S, Stockwell WR, Schoenemeyer T, Forkel R, Michalakes J, Knoche R, Seidl W (2000) Application of a multiscale, coupled MM5/chemistry model to the complex terrain of the VOTALP valley campaign. Atmos Environ 34:1435-1453

Guenther A, Karl T, Harley P, Wiedinmyer C, Palmer PI, Geron C (2006) Estimates of global terrestrial isoprene emissions using MEGAN (model of emissions of gases and aerosols from nature). Atmos Chem Phys 6:3181-3210

Hallquist M, Wenger JC, Baltensperger U, Rudich Y, Simpson D, Claeys M, Dommen J, Donahue NM, George C, Goldstein AH, Hamilton JF, Herrmann H, Hoffman R, Iinuma Y, Jang M, Jenkin ME, Jimenez JL, Kiendler-Scharr A, Maenhaut W, McFiggans G, Menthel TF, Monod A, Prévôt ASH, Seinfeld JH, Surratt JD, Szmigielski R, Wildt J (2009) The formation, properties and impact of secondary organic aerosol: current and emerging issues. Atmos Chem Phys 9:5155-5236

Hauglustaine DA, Hourdin L, Filiberti MA, Walters S, Lamarque JF, Holland EA (2004) Interactive chemistry in the Laboratoire de Météorologie dynamique general circulation model: description and background tropospheric chemistry evaluation. J Geophys Res 109:D043141-D043144

Jacobson MZ (2005) Fundamentals of atmospheric modeling, 2nd edn. Cambrigde, New York

Janjic ZI (1990) The step-mountain coordinate: physical package. Mon Weather Rev 118:1429-1443

Janjic ZI (1994) The step-mountain eta coordinate model: further developments of the convection, viscous sublayer, and turbulence closure schemes. Mon Weather Rev 122:927-945

Janjic ZI (1996) The surface layer in the NCEP Eta Model. In: 11th conference on numerical weather prediction. American Meteorological Society, Norfolk, pp 354-355 
Janjic ZI (2000) Comments on "Development and evaluation of a convection scheme for use in climate models". J Atmos Sci $57: 3686$

Janjic ZI (2001) Nonsingular Implementation of the Mellor-Yamada Level 2.5 Scheme in the NCEP Meso model. Techical report, NCEP, office Note, No. 437

Kaminski JW, Neary L, Struzewska J, McConnell JC, Lupu A, Jarosz J, Toyota K, Gong SL, Côté J, Liu X, Chance K, Richter A (2008) GEM-AQ, an on-line global multiscale chemical weather modelling system: model description and evaluation of gas phase chemistry processes. Atmos Chem Phys 8:3255-3281

Kanamitsu M, Ebisuzaki W, Woollen J, Yang SK, Hnilo JJ, Fiorino M, Potter GL (2002) NCEP-DEO AMIP-II reanalysis (R-2). Bull Atmos Meteorol Soc 11:1631-1643

Korsholm US, Baklanov A, Gross A, Mahura A, Sass BH, Kaas E (2008) Online coupled chemical weather forecasting based on HIRLAM-overview and prospective of Enviro-HIRLAM. HIRLAM Newsl 54:151-168

Liu LJS, Curjuric I, Keidel D, Heldstab J, Künzli N, Bayer-Oglesby L, Ackermann-Liebrich U, Schindler C, SAPALDIA team (2007) Characterization of source-specific air pollution exposure for a large population-based Swiss Cohort (SAPALDIA). Environ Health Perspect 115(11):1638-1645

Liu SC, McKeen SA, Hsie EY, Lin X, Kelly KK, Bradshaw JD, Sandholm ST, Browell EV, Gregory GL, Sachse GW, Bandy AR, Thornton DC, Blake DR, Rowland FS, Newell R, Heikes BG, Singh H, Talbot RW (1996) Model study of tropospheric trace species distributions during PEM-West A. J Geophys Res 101:2073-2085

Matthias V (2008) The aerosol distribution in Europe derived with the community multiscale air quality (CMAQ) model: comparison to near surface in situ and sunphotometer measurements. Atmos Chem Phys 8:5077-5097

McKeen SA, Hsie EY, Trainer M, Tallamaraju R, Liu SC (1991) A regional model study of the ozone budget in the Eastern United States. J Geophys Res 96:10809-10845

Mlawer EJ, Taubman SJ, Brown DP, Iacono MJ, Clough SA (1997) Radiative transfer for inhomogeneous atmospheres: RRTM, a validated correlated-k model for the longwave. J Geophys Res 102:16663-16682

Pay MT, Piot M, Jorba O, Gassó S, Gonçalves M, Basart S, Dabdub D, Jiménez-Guerrero P, Baldasano JM (2010) A full year evaluation of the CALIOPE-EU air quality modeling system over Europe for 2004. Atmos Environ 44(27):3322-3342

Peckham SE, Grell GA, McKeen SA, Fast JD, Gustafson WI, Ghan SJ, Zaveri R, Easter RC, Wiedinmyer C, Schmitz R, Salzmann M, Freitas SR (2010) WRF/Chem Version 3.2 User's Guide. NOAA, PNNL, NCAR, University of Chile, Max Planck Institute for Chemistry, Centro de Previsao de Tempo e Estudos Climaticos

Ritter M (2009) Air pollution modelling for Swizerland. In: Monfardini S (ed) Science and supercomputing in Europe-report 2008, CINECA Consorzio Interuniversitario

Rogers E, Black T, Ferrier B, Lin Y, Parrish D, DiMego G (2001) Changes to the NCEP meso eta analysis and forecast system: increase in resolution, new cloud microphysics, modified precipitation assimilation, modified 3DVAR analysis. http://www.emc.ncep.noaa.gov/mmb/mmbpll/eta12tpb/

Sakulyanontvittaya T, Duhl T, Wiedinmyer C, Helmig D, Matsunaga S, Potosnak M, Milford J, Guenther A (2008) Monoterpene and sesquiterpene emission estimates for the United States. Environ Sci Technol 42:1623-1629

San José R, Pérez JL, Morant JL, González RM (2008) Elevated PM10 and PM2.5 concentrations in Europe: a model experiment with MM5-CMAQ and WRF-CHEM. In: Air Pollution XVI
Schell B, Ackermann IJ, Hass H, Binkowski FS, Ebel A (2001) Modeling the formation of secondary organic aerosol within a comprehensive air quality model system. J Geophys Res 109:28, 275-28, 293

Schmidt H, Derognat C, Vautard R, Beekmann M (2001) A comparison of simulated and observed ozone mixing ratios for the summer of 1998 in Western Europe. Atmos Environ 35:6277-6297

Schürmann GJ, Algieri A, Hedgecock IM, Manna G, Pirrone N, Sprovieri F (2009) Modelling local and synoptic scale influences on ozone concentrations in a topographically complex region of Southern Italy. Atmos Environ 43:4423-4434

Seinfeld JH, Pandis SN (2006) Atmospheric chemistry and physics, 2nd edn. Wiley, Hoboken

Skamarock W, Klemp JB (2008) A time-split nonhydrostatic atmospheric model for weather research and forecasting applications. J Comput Phys 227:3465-3485

Skamarock WC, Klemp JB, Dudhia J, Gill D, Barker DM, Duda MG, Huang XY, Wang W, Powers JG (2008) A description of the advanced research WRF Version 3. Techical report, TN-478+STR, NCAR

Szopa S, Foret G, Menut L, Cozic A (2009) Impact of large scale circulation on European summer surface ozone and consequences for modelling forecast. Atmos Environ 43:1189-1195

Tuccella P, Curci G, Visconti G, Bessagnet B, Menut L, Park R (2012) Modeling of gas and aerosol with WRF/CHEM over Europe: evaluation and sensitivity study. J Geophys Res 117:D03303

Tulet P, Crassier V, Solmon F, Guedalia D, Rosset R (2003) Description of the mesoscale nonhydrostatic chemistry model and application to a transboundary pollution episode between northern France and southern England. J Geophys Res 108(D1):4021

van Loon M, Roemer MGM, Builtjes PJH, Bessagnet B, Rouil L, Christensen JH, Brandt J, Fagerli H, Tarrasón L, Rodgers I (2004) Model inter-comparison in the framework of the review of the unified EMEP model. Techical report R2004/282, TNO

van Loon M, Vautard R, Schaap M, Bergström R, Bessagnet B, Brandt J, Builtjes PJH, Christensen JH, Cuvelier C, Graff A, Jonson JE, Krol M, Langner J, Roberts P, Rouil L, Stern R, Tarrasón L, Thunis P, Vignati E, White L, Wind P (2007) Evaluation of long-term ozone simulations from seven regional air quality models and their ensemble. Atmos Environ 41:2083-2097

Vautard R, Honoré C, Beekmann M, Rouil L (2005) Simulation of ozone during the August 2003 heat wave and emission control scenarios. Atmos Environ 39:2957-2967

Vestreng V, Klein H (2002) Emission data reported to UNECE/ EMEP: quality assurance and trend analysis \& presentation of WebDab techical report, European Environmental Agency, The Norwegian Meteorological Institute, Oslo, Norway, eMEP/ MSC-W NOTE $1 / 2002$

Vogel B, Vogel H, Bäumer D, Bangert M, Lundgren K, Rinke R, Stanelle $T$ (2009) The comprehensive model system COSMOART-radiative impact of aerosol on the state of the atmosphere on the regional scale. Atmos Chem Phys 9:8661-8680

Wild O, Zhu X, Prather MJ (2000) Fast-J: accurate simulation of In- and below-cloud photolysis in tropospheric chemical models. J Atmos Chem 37:245-282

Zaveri RA, Peters LK (1999) A new lumped structure photochemical mechanism for large-scale applications. J Geophys Res 105:30387-30415

Zaveri RA, Easter RC, Fast JD, Peters LK (2008) Model for simulating aerosol interactions and chemistry (MOSAIC). J Geophys Res 113:D13204 